\title{
Note on Texts
}

An Introduction, vol. I of The History of Sexuality, trans. Robert Hurley (New York: Pantheon, 1978). Reprinted as The Will to Knowledge (London: Penguin, 1998). Originally published as La Volonté de savoir (Histoire de la sexualité 1) (Paris: Gallimard, 1976).

\section{Title}

This is a guidebook to the first volume of Michel Foucault's History of Sexuality, which he called The Will to Knowledge (La Volonté de savoir). The book has not generally been known by this title in English, however. It was first translated under the title The History of Sexuality Volume I: An Introduction, which it still bears in North America. Since 1998, though, one British edition published by Penguin has been titled The Will to Knowledge. In every respect other than the cover and frontispiece, all English editions are identical: the content and pagination are the same, being a translation from the French by Robert Hurley.

I prefer the title of The Will to Knowledge, and will generally use it to refer to the text in what follows. The subtitle An Introduction was first used because Foucault initially did intend the first volume to serve as the introduction to his History of Sexuality. However, that project did not unfold as he initially planned: it took longer, and changed form, such that the first volume is no introduction to what comes later.

\section{Translation}

Robert Hurley's translation of the book, used in all editions, is highly readable, but not without faults. To an extent, it prioritises literary style over technical accuracy. Since so many are familiar with his phrasing, 
I retain it where I think it works, but frequently find it inadequate and provide my own alternatives.

Throughout this guidebook, I provide page references to The Will to Knowledge in parentheses. These consist of the page number in Hurley's English translation, followed by a slash, then the page number in the French original. Where I have used my own translation, I add an asterisk $\left(^{*}\right)$ to the reference to indicate this; otherwise, quotations are to the published translation.

Hurley's translation is in American English, hence so are quotations from it. The rest of the book, including my translations, uses British orthography. A similar distinction is observed in relation to the words 'biopolitics' and 'biopower'. While Foucault always in The Will to Knowledge writes 'bio-politics' and 'bio-power', with a hyphen, the hyphen has mostly been dropped in subsequent uses, so I too will dispense with it in my own usage. 
